Research Square

\title{
Determination of CLINDAMYCIN HCl in Capsules by New, Validated, Simple and Green Kinetic Spectrometric Method
}

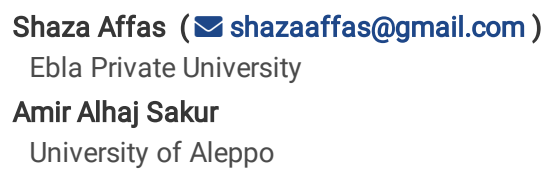

Research Article

Keywords: Clindamycin hydrochloride, spectrophotometry; Kinetic, potassium iodide, potassium iodate; tri iodide.

Posted Date: February 19th, 2021

DOI: https://doi.org/10.21203/rs.3.rs-199417/v1

License: @ (i) This work is licensed under a Creative Commons Attribution 4.0 International License. Read Full License 


\section{Abstract}

Background: simple, sensitive, free of organic solvents, kinetic spectrophotometric method has been developed for the determination of Clindamycin Hydrochloride, both in pure form and Capsules. Method used is based on reaction of Clindamycin with potassium iodide and potassium iodate in aqueous medium at $\left(25 \pm 2{ }^{\circ} \mathrm{C}\right)$ to produce yellow colored tri iodide ions (I3-). the reaction is followed spectrophotometrically by measuring the absorbance at $350 \mathrm{~nm}$ wavelength during 40 minutes.

Results: the effects of analytical parameters on reported kinetic methods were investigated. Under the optimized conditions, the initial rate and fixed time (at $10 \mathrm{~min}$ ) methods were used for constructing the calibration graphs. The graphs were linear in concentration ranges 1-20 $\mu$ g.ml- 1 with limit of detection of 0.12 and $0.22 \mu \mathrm{g} \mathrm{ml}-1$ for the initial rate and fixed time methods, respectively. The results were satisfactory and the analytical performance for both methods was validated.

Conclusion: The proposed methods have been applied to determine the components in capsules with an average recovery of $98.25 \%$ to $102.00 \%$ and the results are in good agreement with those found by the reference method.

\section{Introduction}

Clindamycin (CLN), (methyl-7-chloro-6,7,8-trideoxy-6-\{[4R)-1-methyl-4-propyl-L-prolyl]amino\}-1-thio-L-threo-3-Dgalacto-octopyranoside), (Figure1) is a semisynthetic analog of lincomycin.

Clindamycin restricts the synthesis of bacterial proteins by binding to the 50 S subunit of the ribosome[1]. It is active against Gram-positive aerobic and anaerobic, as well as-some Gram-negative aerobic bacteria. [1]

It works similar to a bacteriostatic antibiotic. common clinical conditions in which they are included were: gynaecology infections, gingiva infections, respiratory tract infections, skin and soft tissue infections, intra-abdominal infections, pneumonia caused by Pneumocystis, toxoplasmosis, malaria, babesiosis, and acne[2]. Clindamycin is existing in a wide variety of prescription formulations that can be given orally or intradermal[2].

The research showed various methods for deamination of clindamycin. The United States Pharmacopoeia (USP) suggested the technique of liquid chromatography for the Clindamycin assay [3]. there are a variety of analytical techniques for the study of Clindamycin in various pharmaceutical formulations, as well as in biological samples.

High-performance liquid chromatography (HPLC) is the most commonly used [2,4-9], potentiometric determination [10] capillary electrophoresis [11], micellar chromatography[12], chemiluminescence methods [13], voltammetry [14-16] and Spectrophotometric determination that dependent on color forming [17-18].

In previous publicans, the spectrophotometric estimation of Clindamycin based on the spectrophotometric method that includes the oxidation of the sulfur ato drug in an acidic medium.

with the liberation of iodine and subsequent extraction with cyclohexane, then measuring the absorbance at 520 nm [17], other spectrophotometric method involves the formation of ion pair complex between Clindamycin hydrochloride and rose bengal in slightly basic medium ( $\mathrm{pH} 7.5)$. The color formed is measured $555 \mathrm{~nm}[18]$

The proposed UV-Vis spectrophotometric method allows analyzing the content of clindamycin hydrochloride in capsules.

There is no research about determination of CLN.HCl based on kinetic amethods.

kinetic methods have advantages such as selectivity and reduction of interference with excipients, therefore there is a need for a kinetic method to determine CLN.HCl.

The aim of the present study was to report new kinetic spectrophotometric method that is simple and precise for the determination of CLN.HCl as raw materials and in capsules with no interference with other ingredients in their forms. The suggested approach is more economically safe than other approaches that use organic solvents and reagents, and focuses on the interaction between the Potassium lodide and Potassium lodide products.

\section{Materials And Methods}

\section{apparatus}

uv-visible spectrophotometer (JASCO, model V650, Japan) with $1.00 \mathrm{~cm}$ quartz cells. Ultrasonic processor (Powersonic, model 405, Korea) was used to sonicate the sample solutions. Adjustable micro pipettes covering a volume range from 2 to $2000 \mu \mathrm{L}$ (ISO-LAB, Germany), used for preparation of the experimental solutions.

Analytical balance (Sartorius, model 2474, Germany).

\section{materials}

Pharmaceutical grade Clindamycin $\mathrm{HCl}(99 \%)$ were received from XUHUANG, CHINA.

Potassium iodide and potassium iodate (Panreac, Germany). 
All chemicals used were of analytical reliability.

Standard solution ( $1 \mathrm{mg} \cdot \mathrm{ml}^{-1}$ ) of CLN.HCl was prepared by dissolving $25 \mathrm{mg}$ of $\mathrm{CLN} . \mathrm{HCl}$ in $25 \mathrm{ml}$ of double distilled water.

$0.2 \mathrm{M}$ of potassium iodate and $0.3 \mathrm{M}$ of potassium iodide solutions were prepared by dissolving the weighed amount of the pure solid in double distilled water.

All solutions were stable for a time of 2 days when stored at $\left(5^{\circ} \mathrm{C}\right)$

I - General Procedure for Kinetic Study

Increasing amounts of CLN.HCl working normal solution have been moved to a set of $10 \mathrm{ml}$ volumetric flasks containing $3 \mathrm{ml} \mathrm{KI}(0.3 \mathrm{M})$ and $1 \mathrm{ml} \mathrm{KIO3} \mathrm{(0.2}$ $\mathrm{M})$.

The volume was made up to the mark with distilled water and the absorbance was estimated at $350 \mathrm{~nm}$ at $0,5,10,15,20,25,30,35$ and 40 minutes.

All measurements were performed at room temperature $\left(25 \pm 2^{\circ} \mathrm{C}\right)$

\section{2- Procedure for Calibration}

\subsection{Initial rate method}

Initial reaction rates were measured by calculating the slopes of the initial tangent to the absorbance time curves.

In order to achieve final concentrations between(0.5-30) $\mu \mathrm{g} \mathrm{ml-1}$ of $\mathrm{CLN}$.HCl, liquots of the CLN.HCl research solution is pipetted into a series of $10 \mathrm{ml}$ regular flasks.

To each flask, $3 \mathrm{ml}$ of $\mathrm{KI}(0.3 \mathrm{M})$ and $1 \mathrm{ml}$ of $\mathrm{KIO}(0.2 \mathrm{M})$ were added and then diluted with distilled water.

The contents of each flask's mixture were well mixed and the increase in absorbance was reported as a function of time at $350 \mathrm{~nm}$. From the slope of the tangent to the absorbance-time curve, the initial reaction rate $(\mathrm{n})$ at different concentrations was obtained.

\subsection{Fixed time method:}

In this method, the absorption of a yellow-colored solutions containing varying quantities of drug was measured at a preselected fixed time, 10 min, as defined above for the initial rate method.

\section{3-Result and Discussion}

\section{3-1- Construction of calibration:}

The absorbance data of kinetic tracks at $0 \mathrm{~min}$ and $40 \mathrm{~min}$ are used to construct calibration. The average relative responses of 5 repeats were evaluated. The absorbance falling within $98 \%$ to $102 \%$ of average relative response only are considered in construction of the calibration curve [Fig.3]. The limits of Beer's law, slope, intercept, correlation coefficient, and regression equation for each drug are tabulated in [Table 1].

\section{3-2- Method validation}

The method developed for the estimation of the drug has been validated in terms of accuracy, precision and detection limits,

Absorbance-time curves were drawn, and the substance recovery was measured using initial rate and fixed time methods.

To evaluate the precision, each experiment was repeated at least 5 times and accuracy is estimated in terms of percent recovery and percent RSD. Good percent recovery and RSD being less than 2 indicates the accuracy and precision of the methods. Using a standard reference method, t-test and F-test values were also measured. The t-test and F-test values are less than their acceptable range indicating high accuracy and precision of the methods [Table 2].

To test the selectivity, known excipients of each drug were added to the pure drug sample and recovery experiments were performed. Ruggedness is method resistance for a minor change in variables such as instrument and expert, or both. Using 3 different instruments and 2 analysts, 3 different instruments and 2 analysts were reported to test the robustness of the absorption method results. No significant changes were detected either by instrument or analyst alteration, so the process can be maintained as rough.

\section{3-3-Procedure for pharmaceutical formulations}

The content of twenty separate capsules were weighed. An accurately weighed amount of the powder equivalent to $50 \mathrm{mg}$ of CLN.HCl, was moved into volumetric flask and dissolve in $50 \mathrm{ml}$ of water. The content was sonicated for $10 \mathrm{~min}$. A portion of this solution was centrifuged for $15 \mathrm{~min}$ at $5000 \mathrm{rpm}$, suitable volume of the supernatant was transferred into $10 \mathrm{ml}$ volumetric flask and procedure was continued to use for the analysis of CLN.HCl by the proposed spectrophotometric method.

\section{Results}


lodide ions transform to free iodine in an acidic medium of $\mathrm{CLN}$. $\mathrm{HCl}$ solution, the acidity comes from $\mathrm{HCl}$ then free iodine reacts with an excess of iodide ions to form yellow complex from tri iodide $\left(\beta^{3-}\right)$ (Figure 2)[20- 21].

$1 \mathrm{O}_{3}^{-}+5 \mathrm{I}^{-}+6 \mathrm{H}^{+} \rightarrow 2 \mathrm{I}_{3}^{-}+3 \mathrm{H}_{2} \mathrm{O}$

\section{Reaction conditions}

The ideal conditions for the improvement of method were established by changing the parameters one at a time and keeping the others fixed and observing the influence produced on the absorbance of the colored products.

The effect of various parameters such as volumes of $\mathrm{KIO}_{3}, \mathrm{KI}$, and temperature were studied, in order to found experimental conditions.

A volume of $3 \mathrm{ml}$ of $0.3 \mathrm{M} \mathrm{Kl}, 1 \mathrm{ml}$ of $0.1 \mathrm{M} \mathrm{KIO}_{3}$ were found to be optimum for maximum color advance for determination of CLN.HCl, since the absorbance were found to be maxima at the stated volumes. The laboratory temperature was $\left(25 \pm 2{ }^{\circ} \mathrm{C}\right)$.

At (25-35) $\mathrm{C}^{\circ}$ the reaction rate of drug improved significantly as the color development increased. Room temperature was selected as the optimal.

\section{Calibration graphs}

Initial rate method: The initial reaction rate at various concentrations was calculated from the slope of the tangent to the absorbance time curve The calibration graph was constructed by plotting the logarithm of the initial reaction rate against the logarithm of the molar concentration of $\mathrm{CLN}$. $\mathrm{HCl}$. The rate data of reaction would follow a pseudo order rate constant and submitted the following rate equation:

$v=\frac{\Delta \mathrm{C}}{\Delta \mathrm{t}}=\frac{\Delta \mathrm{A}}{\Delta \mathrm{t}}=\mathrm{K} \cdot \mathrm{C}^{\mathrm{n}}$

Where:

$v$ is the reaction rate, $A$ is the absorbance., $\Delta A=A t_{2}-A t_{1}, t$ is the measuring period, $\Delta t=t 2-t 1$

$\mathrm{k}^{\prime}$ is the pseudo order rate constant, $\mathrm{C}$ is the concentration of the $\mathrm{V}(\mathrm{V}) \mathrm{mol} / \mathrm{L}$

and $\mathrm{n}$ is the order of the reaction.

A calibration curve was constructed by plotting the logarithm of the initial rate of reaction (log $\mathrm{v})$ against logarithm of $\mathrm{V}(\mathrm{V})$ concentration (log $\mathrm{C})$, which showed a linear relationship over the concentration range of (1-20) $\mathrm{mg} / \mathrm{L}$ (Figure 4).

the equation is written as follows:

$\log v=\log \Delta \mathrm{A} / \Delta \mathrm{t}=\log \mathrm{k}^{\prime}+\mathrm{n} \log \mathrm{C}$

$\log V=\log \Delta \mathrm{A} / \Delta \mathrm{t}=0.9722 \log \mathrm{C}-1.4793$

Thus, $\mathrm{k}^{\prime}=30.15 \mathrm{Sec}^{-1}$, and the reaction is the first order $(\mathrm{n}=0.9722=1)$ with respect to $\mathrm{V}(\mathrm{V})$ concentration.

\subsubsection{Rate constant method:}

The logarithm of the absorbance contrasted with time for each concentration of $\mathrm{V}(\mathrm{V})$ which investigated over the concentration rang of 1$20 \mathrm{mg} / \mathrm{L}$ was estimated.

Graphs of log absorbance versus time for $\mathrm{V}(\mathrm{V})$ concentration in the range of 1-8 $\mathrm{mg} / \mathrm{L}\left(1.570 \times 10^{-4}-2.355 \times 10^{-4}\right)$ were plotted. Pseudo order rate constant ( $\left.\mathrm{k}\right)$ corresponding to $\mathrm{V}(\mathrm{V})$ concentrations is determined from the slopes multiplied by-2,303 and are shown in (Figure 5 ). Regression of $\mathrm{C}$ versus $\mathrm{k}^{\prime}$ gave equation: $y=5.6352 x-21.459\left(R^{2}=0.6234\right)$.

\subsubsection{Fixed absorbance method:}

Reaction rate data were recorded for different concentrations of $\mathrm{V}(\mathrm{CLN})$ in the range $10-20 \mathrm{mg} / \mathrm{L}\left(2.239 \times 10^{-5}-4.334 \times 10^{-5}\right) \mathrm{M}$. The preselected absorbance value of 1.2 was set and the time was calculated in seconds. The reciprocal of time (1/t) versus the initial concentration of V(CLN) was plotted (Figure 6$)$ and the following equation of calibration graph was found.

$1 / t=693.99 C-0.0157(r 0.8452)$

\subsubsection{Fixed time method:}

At preselected fixed time, the absorbance of solution containing varying amounts of $\mathrm{V}(\mathrm{CLN})$ was measured at $25^{\circ} \mathrm{C}$ and $530 \mathrm{~nm}$. Calibration graphs were built by plotting the absorbance against the initial concentration of $\mathrm{V}(\mathrm{CLN})$ at a fixed time of $0-2400 \mathrm{sec}(40 \mathrm{~min})$. The regression equations, correlation coefficients and linear ranges are given in (Table 1). It is clear that, the slope increases with the time and the most acceptable value of $r$ was obtained for a fixed time of $600 \mathrm{Sec}$ (Figure 7). Therefore, the fixed time of $600 \mathrm{Sec}$ was utilized for the assay of (CLN) concentration. 
Table 1. Regression equations for CLN at a fixed time and $25^{\circ} \mathrm{C}$.

\begin{tabular}{|l|l|l|l|}
\hline Time (min) & Regression equation & Correlation Coefficient & Linear range \\
\hline 300 & $\mathrm{~A}=0.0883 \mathrm{C}-0.0098$ & $\mathrm{R} \rrbracket=0.9996$ & $1-20 \mathrm{mg} / \mathrm{L}$ \\
\hline 600 & $\mathrm{~A}=0.0996 \mathrm{C}-0.0064$ & $\mathrm{R} \square=0.9999$ & $1-20 \mathrm{mg} / \mathrm{L}$ \\
\hline 900 & $\mathrm{~A}=0.1053 \mathrm{C}-0.0023$ & $\mathrm{R} \square=0.9998$ & $1-20 \mathrm{mg} / \mathrm{L}$ \\
\hline 1200 & $\mathrm{~A}=0.1078 \mathrm{C}+0.0069$ & $\mathrm{R} \square=0.9998$ & $1-20 \mathrm{mg} / \mathrm{L}$ \\
\hline 1500 & $\mathrm{~A}=0.1103 \mathrm{C}+0.0042$ & $\mathrm{R}]=0.9997$ & $1-20 \mathrm{mg} / \mathrm{L}$ \\
\hline 1800 & $\mathrm{~A}=0.1139 \mathrm{C}-0.0026$ & $\mathrm{R} \square=0.9999$ & $1-20 \mathrm{mg} / \mathrm{L}$ \\
\hline 2100 & $\mathrm{~A}=0.1146 \mathrm{C}+0.0126$ & $\mathrm{R} \square=0.9997$ & $1-20 \mathrm{mg} / \mathrm{L}$ \\
\hline 2400 & $\mathrm{~A}=0.119 \mathrm{C}+0.0101$ & $\mathrm{R} \square=0.9994$ & $1-20 \mathrm{mg} / \mathrm{L}$ \\
\hline
\end{tabular}

A: absorbance, C: concentration

\section{method validation}

\subsubsection{Calibration graph}

The Correlation coefficient, intercept and slope values for the calibration data determined by using the least square method [21]. The slopes and the intercepts are rising over time. The most suitable values for the correlation coefficient of reaction products were found at 600 sec as a fixed time, which was selected as the most effective time for measurements (Table 2). After changing the reaction conditions, a fixed time procedure was used for the determination of CLN in Capsules over a concentration range of $2-12 \mathrm{mg} / \mathrm{L}$. The minimum amount at which the analyzed compound can be accurately detected (detection maximum, LOD) was experimentally calculated for the fixed time $(600 \mathrm{sec})$ method and was found to be $0.119 \mathrm{mg} / \mathrm{L}$.

Table 2. Analytical characteristics of the fixed time (600 Sec) method.

\begin{tabular}{|l|c|}
\hline \multicolumn{1}{|c|}{ Parameters } & CLN \\
\cline { 2 - 2 } & Fixed time method \\
\hline Linear rang $\mu \mathrm{g} \cdot \mathrm{ml}^{-1}$ & $1-20$ \\
\hline$\square \mathrm{l} \mathrm{mol}^{-1} \mathrm{~cm}^{-1}$ & $45.135 \times 10^{3}$ \\
\hline Detection limit $\mu \mathrm{g} \cdot \mathrm{ml}^{-1}$ & 0.12 \\
\hline $\begin{array}{l}\text { Limit of quantification } \\
\mu \mathrm{g} \cdot \mathrm{ml}^{-1}\end{array}$ & 0.39 \\
\hline Regression equation & $*($ \\
\cline { 2 - 2 } & $\mathrm{m}=0.099$ \\
\cline { 2 - 2 } & $\mathrm{b}=0.006$ \\
\hline Correlation coefficient & 0.9999 \\
\hline
\end{tabular}

* Concerning $\mathrm{A}=\mathrm{mC}+\mathrm{b}$, where $\mathrm{C}$ is the concentration $\left(\mu \mathrm{g} \cdot \mathrm{ml}^{-1}\right.$ ) and $\mathrm{A}$ is the absorbance.

\section{Accuracy and Precision:}

The accuracy and precision of the proposed procedures were carried out by five determinations at several different concentrations for CLN. Percentage relative standard deviation (RSD \%) and the percentage recovery of the suggested procedures were calculated and showed in Table 3 . Values of relative standard deviations for various drug concentrations calculated by the calibration curves. These findings of accuracy and precision indicate that the methods suggested have reasonable repeatability and reproducibility. The suggested procedure was found to be selective for the CLN. HCl test in the presence of various excipients.

Table 3: Accuracy and precision for the determination of SIL and VAR in bulk powder by the proposed method:

\begin{tabular}{|c|c|c|c|c|c|c|}
\hline \multirow{2}{*}{$\begin{array}{c}\text { Drug } \\
C L N . H C l\end{array}$} & \multirow{2}{*}{$\begin{array}{c}\text { Method } \\
\text { Fixed time }\end{array}$} & \multicolumn{3}{|c|}{$\mathrm{mg} / \mathrm{ml}$} & \multirow[t]{2}{*}{$R S D \%$} & \multirow[t]{2}{*}{ \%Recovery } \\
\hline & & Taken & Found & $S . D^{*}$ & & \\
\hline & & 1 & 1.018 & 0.011 & 1.08 & 101.81 \\
\hline & & 2 & 1.996 & 0.034 & 1.68 & 99.80 \\
\hline & & 4 & 3.980 & 0.013 & 0.33 & 99.50 \\
\hline & & 8 & 8.056 & 0.022 & 0.27 & 100.70 \\
\hline & & 16 & 16.069 & 0.075 & 0.47 & 100.43 \\
\hline & & 20 & 20.337 & 0.398 & 1.96 & 101.69 \\
\hline & Initial rate & 1 & 1.020 & 0.017 & 1.67 & 102.00 \\
\hline & & $\overline{2}$ & 2.035 & 0.040 & 1.97 & 101.75 \\
\hline & & 4 & 3.930 & 0.012 & 0.31 & 98.25 \\
\hline & & 8 & 8.100 & 0.120 & 1.48 & 101.25 \\
\hline & & 16 & 16.100 & 0.200 & 1.24 & 100.63 \\
\hline & & 20 & 19.890 & 0.320 & 1.61 & 99.45 \\
\hline
\end{tabular}

Analysis of Clindamycin Hydrochloride in capsules:

For the determination of CLN in capsules, the developed kinetic spectrophotometric method was used. The findings in Table 4 show high precision and accuracy.

As can be seen from Table 3, the advantage of the proposed approach is that it is virtually free from interference by excipients and typical degradation materials. 
The results obtained were compared statistically by the student's t-test (for accuracy) and the variance ratio F-test (for precision) with those obtained by the reference methods $[3,23]$ on samples of the same batch (Table 3). The values of $t$ - and F-tests obtained at $95 \%$ confidence level and four degrees of freedom did not exceed the theoretical value indicating any significant difference between the suggested method and reference method.

Table 3: Determination of CLN.HCl in their pharmaceutical preparations using the proposed kinetic methods and reference methods

\begin{tabular}{|c|c|c|c|c|c|}
\hline \multirow[t]{3}{*}{ Formula } & \multirow[t]{3}{*}{ Drug } & \multirow{3}{*}{$\begin{array}{c}\text { Claim } \\
\text { (mg/tab) }\end{array}$} & \multicolumn{3}{|c|}{ Recovery \% $\%$ S.D* } \\
\hline & & & \multicolumn{2}{|c|}{ Proposed kinetic method } & \multirow[t]{2}{*}{ Reference method [3] } \\
\hline & & & Fixed time & Initial rate & \\
\hline \multirow[t]{3}{*}{ Clindo** } & \multirow[t]{3}{*}{ CLN } & 75 & $\begin{array}{c}99.13 \% \pm 2.07 \\
t=1.76 \\
F=2.83\end{array}$ & $\begin{array}{c}98.97 \pm 1.34 \\
t=1.64 \\
F=2.87\end{array}$ & $\begin{array}{c}100.16 \% \pm 0.25 \\
t=1.42\end{array}$ \\
\hline & & 150 & $\begin{array}{c}101.12 \% \pm 0.63 \\
t=2.08 \\
F=2.45\end{array}$ & $\begin{array}{c}100.83 \% \pm 1.36 \\
t=1.93 \\
F=2.39\end{array}$ & $\begin{array}{c}101.16 \% \pm 1.02 \\
t=1.54\end{array}$ \\
\hline & & 300 & $\begin{array}{c}100.18 \% \pm 0.99 \\
t=1.84 \\
F=2.13\end{array}$ & $\begin{array}{c}100.89 \% \pm 1.03 \\
t=2.45 \\
F=1.98\end{array}$ & $\begin{array}{c}100.75 \% \pm 0.28 \\
t=1.13\end{array}$ \\
\hline & & & Fixed Time & Initial Rate & \\
\hline \multirow[t]{3}{*}{$\begin{array}{l}\text { CLINDAMYCIN } \\
\text { BIOMED**** }\end{array}$} & \multirow[t]{3}{*}{ CLN } & 75 & $\begin{array}{c}99.19 \% \pm 0.69 \\
t=0.16 \\
F=2.39\end{array}$ & $\begin{array}{c}100.15 \% \pm 1.38 \\
t=1.56 \\
F=2.18\end{array}$ & $\begin{array}{c}100.53 \% \pm 1.02 \\
t=0.83\end{array}$ \\
\hline & & 150 & $\begin{array}{c}99.25 \% \pm 1.17 \\
t=1.46 \\
F=2.37\end{array}$ & $\begin{array}{c}100.25 \% \pm 0.87 \\
t=2.10 \\
F=2.67\end{array}$ & $\begin{array}{c}101.19 \% \pm 1.00 \\
t=0.79\end{array}$ \\
\hline & & 300 & $\begin{array}{c}100.29 \% \pm 1.19 \\
t=1.18 \\
F=2.72\end{array}$ & $\begin{array}{c}101.50 \% \pm 1.05 \\
t=1.82 \\
F=2.28\end{array}$ & $\begin{array}{c}100.76 \% \pm 0.89 \\
t=1.09\end{array}$ \\
\hline
\end{tabular}

* Five independent analyses (four degrees of freedom). At 95\% confidence level t-value is 2.776 and F-value is 6.26 **Supplied by AL-SAAD products $\square$ Syria.

***Supplied by BIOMED products, Syria.

\section{Conclusion}

The suggested kinetic analytical procedures were quick, accurate and precise, so it could be used for the routine analysis of Clindamycin $\mathrm{HCl}$ in bulk and capsules. Sample recoveries are in full compliance with their respective label statements, which indicated that non-interference of formulations excipients in the assay.

Moreover, all the analytical reagents are reasonably priced, and the present method is environmentally safe because it doesn't need any organic reagents or solvents, it is free extractive and also very sensitive comparing with the other spectrophotometric methods.

\section{Declarations}

\section{Conflict of interests}

The authors have declared that no conflict of interests exists.

\section{References}

[1] Wayne, P., 2014. Clinical and Laboratory Standards Institute: Performance standards for antimicrobial susceptibility testing: Twenty-fourth informational supplement, M100-S24. Clinical and Laboratory Standards Institute (CLSI), 34(1).

[2] Mifsud, M., Vella, J., Ferrito, V., Serracino-Inglott, A., Azzopardi, L.M., Sammut Bartolo, N., LaFerla, G. and Sammut, C., 2014. A simple HPLC-UV method for the determination of clindamycin in human plasma.

[3] (USP 29-NF 24 Page 536)

[4] Olbrich, J. and Corbett, J., 2013. Development and Utilization of Reversed Phase High Performance Liquid Chromatography Methods for a Series of Therapeutic Agents. Modern Chemistry \& Applications.

[5] Modi, P.B. and Shah, N.J., 2014. Novel stability-indicating RP-HPLC method for the simultaneous estimation of clindamycin phosphate and adapalene along with preservatives in topical gel formulations. Scientia Pharmaceutica, 82(4), pp.799-814.

[6] Potnuri, N.R., Rao, D.G. and Prasad, R.Y., 2015. A novel stability indicating RP-HPLC method for the simultaneous estimation of moxifloxacin and prednisolone in bulk and their combined dosage form. International Journal of Pharmaceutical Sciences and Research, 6(5), p.1965. 
[7]Batzias, G.C., Delis, G.A. and Koutsoviti-Papadopoulou, M., 2004. A new HPLC/UV method for the determination of clindamycin in dog blood serum. Journal of pharmaceutical and biomedical analysis, 35(3), pp.545-554.

[8] Stanković, M., Savić, V. and Marinković, V., 2013. Determination of clindamycin phosphate in different vaginal gel formulations by reverse phase high performance liquid chromatography. Acta Facultatis Medicae Naissensis, 30(2), pp.63-71.

[9] Wu, G.K., Gupta, A., Khan, M.A. and Faustino, P.J., 2013. Development and Application of a Validated HPLC Method for the Determination of Clindamycin Palmitate Hydrochloride in Marketed Drug Products: An Optimization of the Current USP Methodology for Assay. Journal of Analytical Sciences, Methods and Instrumentation, 2013.

[10] Rizk, M.S., Merey, H.A., Tawakkol, S.M. and Sweilam, M.N., 2013. New potentiometric determination of clindamycin hydrochloride in pharmaceuticals.

[11] Flurer, C.L. and Wolnik, K.A., 1994. Chemical profiling of pharmaceuticals by capillary electrophoresis in the determination of drug origin. Journal of Chromatography A, 674(1-2), pp.153-163.

[12] Dehouck, P., Van Schepdael, A., Roets, E. and Hoogmartens, J., 2001. Analysis of clindamycin by micellar electrokinetic chromatography with a mixed micellar system. Journal of Chromatography A, 932(1-2), pp.145-152.

[13] Shao, X., Xie, X., Liu, Y. and Song, Z., 2006. Rapid determination of clindamycin in medicine with myoglobin-luminol chemiluminescence system. Journal of pharmaceutical and biomedical analysis, 41(2), pp.667-670.

[14] Norouzi, P., Larijani, B., Ezoddin, M. and Ganjali, M.R., 2008. Sub-second adsorption for the fast sub-nanomolar monitoring of Clindamycin in its pure and pharmaceutical samples by fast Fourier transformation with the use of continuous cyclic voltammetry at an Au microelectrode in a flowing system. Materials Science and Engineering: C, 28(1), pp.87-93.

[15] Habib, I.H.I., Rizk, M.S. and El-Aryan, T.R., 2011. Determination of clindamycin in dosage forms and biological samples by adsorption stripping voltammetry with carbon paste electrode. Pharmaceutical Chemistry Journal, 44(12), p.705.

[16] Elzanfaly, E.S., Zaazaa, H.E. and Merey, H.A., 2013. Ion selective phosphotungestate and $\beta$-cyclodextrin based membrane electrodes for stability-indicating determination of midodrine hydrochloride. Acta Chimica Slovenica, 60(2), pp.256-262.

[17] El-Yazbi, F.A. and Blaih, S.M., 1993. Spectrophotometric and titrimetric determination of clindamycin hydrochloride in pharmaceutical preparations. Analyst, 118(5), pp.577-579.

[19] Amin, A.S., 1995. Spectrophotometric and conductometric determination of clindamycin hydrochloride in pure form and in pharmaceutical preparations. Analusis, 8(23), pp.415-417.

[20] Khateeb, M., Elias, B. and Al Rahal, F., 2015. Validated spectrophotometric method to Assay of B6 and B3 vitamins in pharmaceutical forms using potassium iodide and potassium iodate. International Letters of Chemistry, Physics and Astronomy, 60, pp.113-119.

[21] Sakur, A.A. and Affas, S., 2017. Validated spectrophotometric method to determine vardenafil and sildenafil in pharmaceutical forms using potassium iodide and potassium iodate. Int J Pharm Pharm Sci, 9(11), pp.65-9.

\section{Figures}

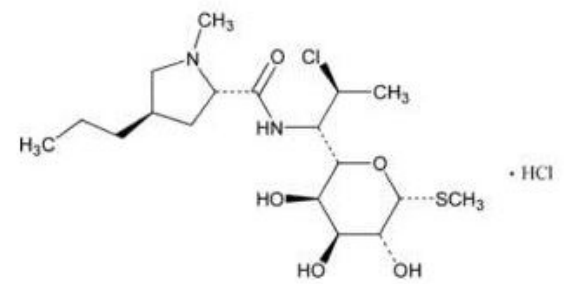

Figure 1

Clindamycin $\mathrm{HCl}$ 


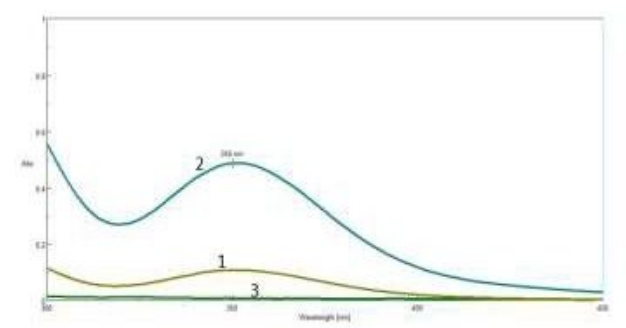

Figure 2

(1) Blank $(\mathrm{I}+\mathrm{KI})$ against distilled water, (2) CLN.HCl $(5 \mu \mathrm{g} \mathrm{ml}-1)+3 \mathrm{ml}$ of $0.30 \mathrm{M} \mathrm{KI}+2.0 \mathrm{ml}$ of $0.1 \mathrm{M} \mathrm{KIO3} \mathrm{against} \mathrm{Blank,} \mathrm{(3)} \mathrm{CLN} \mathrm{against} \mathrm{water.}$

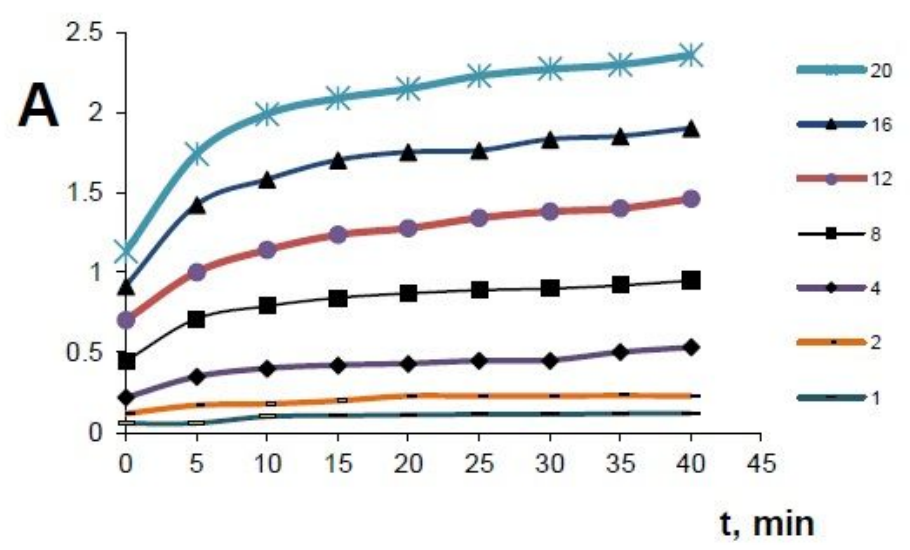

Figure 3

Absorbance - time curve for CLN.HCL+reagent (KI+KIO3) Concentrations of CLN.HCL:: (1)1 ppm; (2)2 ppm; (3)4 ppm ;(4)8 ppm ; (5)12 ppm, (5)16 ppm, (6) 20 ppm

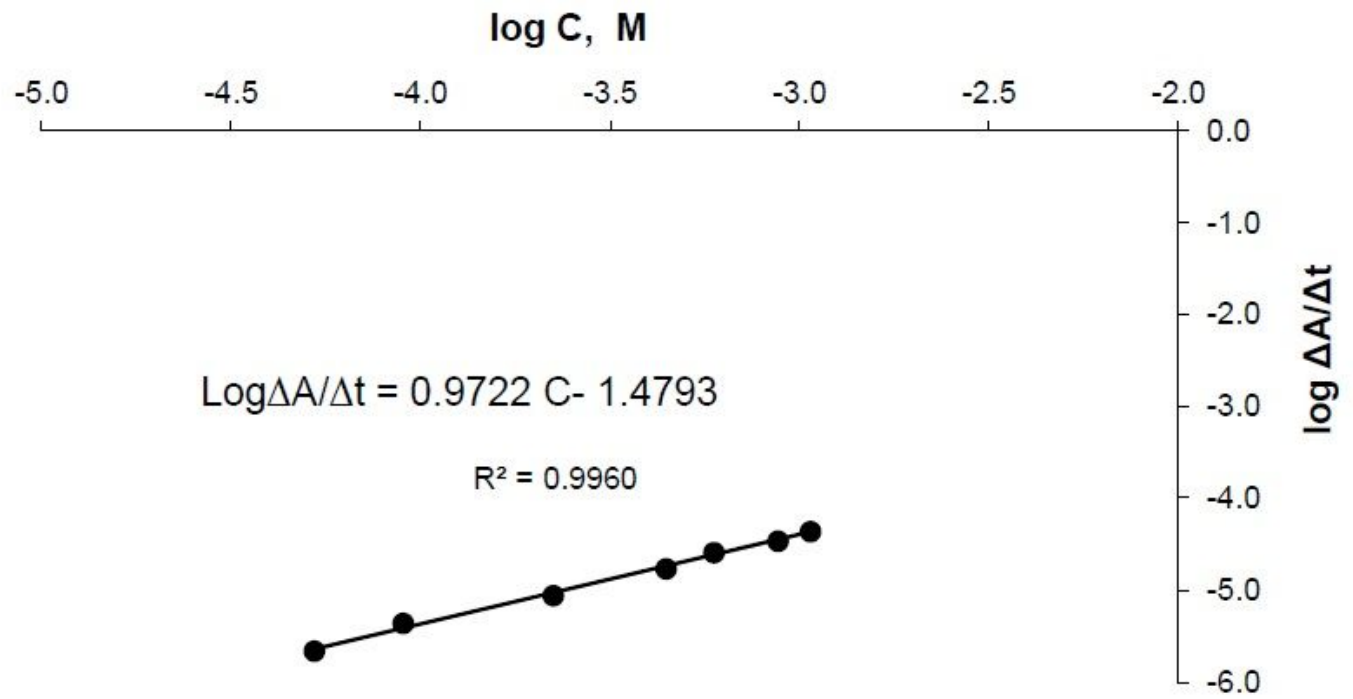

Figure 4

logarithm $(\triangle \mathrm{A} / \Delta \mathrm{t})$ versus the logarithm of $(\mathrm{CCLN})$ curve 


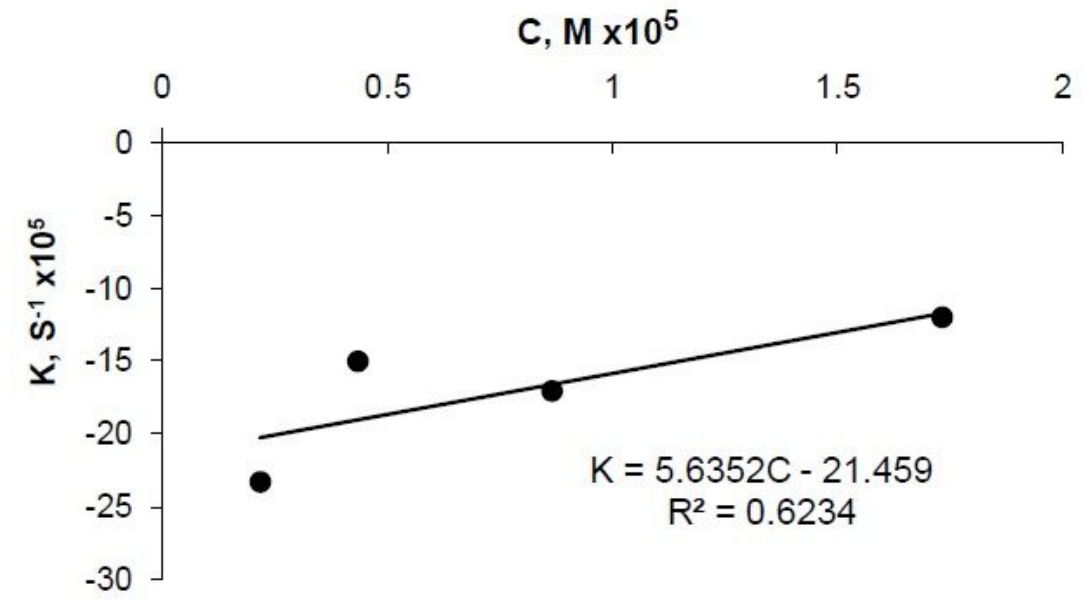

Figure 5

Rate constant method calibration curve for CLN.HCl

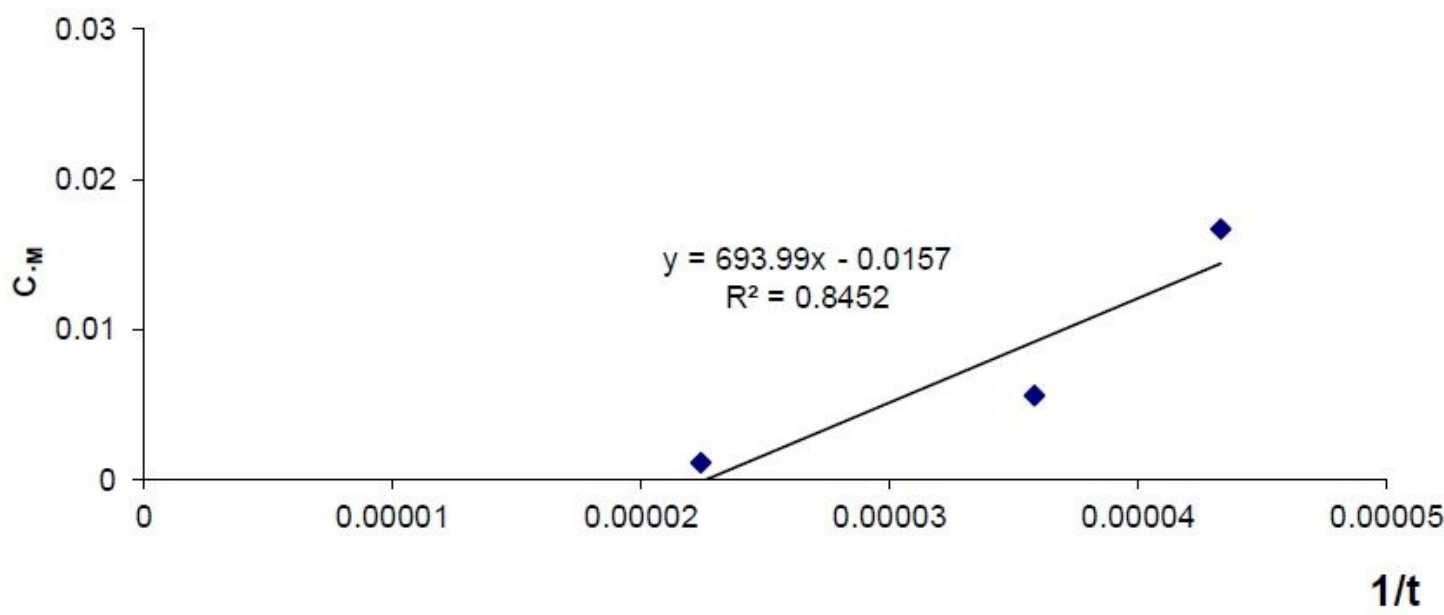

Figure 6

graph for determining CLN.HCl by fixed absorbance method

$10 \mathrm{~min}$

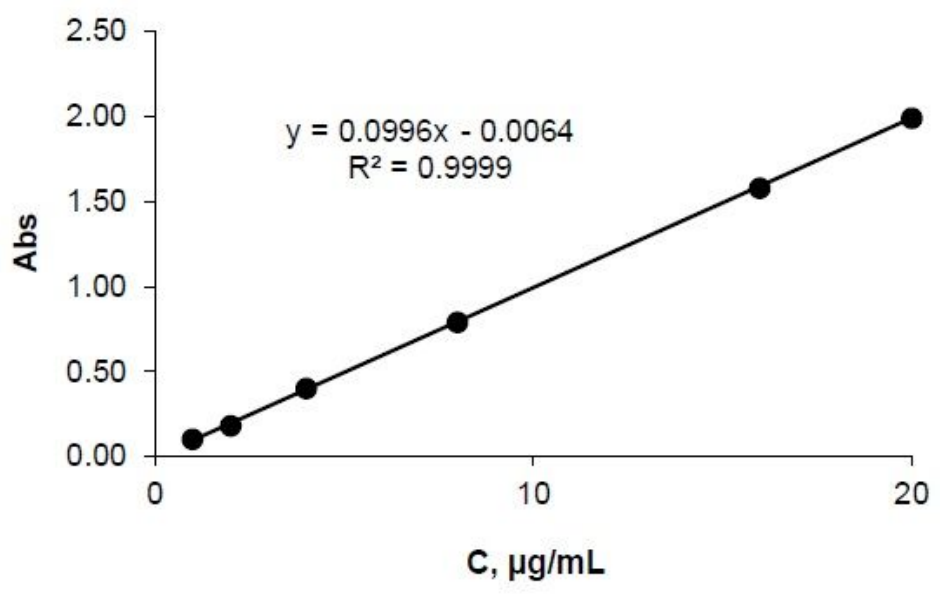

Figure 7

graph for determining CLN.HCl by fixed time method $(t=10 \mathrm{~min}) \mathrm{CLN} . \mathrm{HCl}$ by fixed time method $(t=10 \mathrm{~min}$.) 